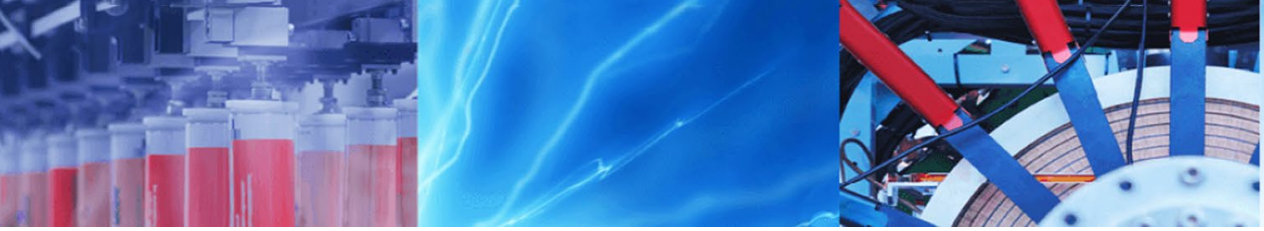

Research Article

\title{
Thorium ions recovery using activated carbon modified with triphenyl phosphine oxide: kinetic and equilibrium studies
}

\author{
Lamia A. Yousef ${ }^{1} \cdot$ Ahmed R. Bakry $^{1} \cdot$ Ahmad A. Ahmad $^{1}$
}

(c) Springer Nature Switzerland AG 2019

\begin{abstract}
Activated carbon (AC) modified with triphenyl phosphine oxide (TPPO) was tested for thorium(IV) adsorption. Different factors affecting the adsorption process such as $\mathrm{pH}$, contact time, modified AC dose, initial thorium concentration, triphenyl phosphine oxide (TPPO) concentration and temperature were investigated to optimize Th(IV) adsorption operating conditions. Kinetic and equilibrium studies of the adsorption process have been studied. The obtained most favorable conditions for Th(IV) adsorption were: $\mathrm{pH} 3.6,40$ min contact time, $0.5 \mathrm{~g}$ modified AC dose, $0.02 \mathrm{M} \mathrm{TPPO}$ in toluene and $400 \mathrm{mg} / \mathrm{L}$ of thorium concentration at room temperature. The maximum sorption capacity according to Langmuir isotherm reached $71.94 \mathrm{mg} / \mathrm{g}$ for modified AC. Adsorption kinetics obeys pseudo-second order kinetic model. Thorium(IV) was efficiently desorbed from the loaded composite using $0.5 \mathrm{M} \mathrm{H}_{2} \mathrm{SO}_{4}$ solution. The optimized factors have been carried out to recover thorium(IV) from Abu Rusheid leach liquor, south Eastern Desert, Egypt.
\end{abstract}

Keywords Modified AC · TPPO - Thorium · Recovery

\section{Introduction}

Thorium is widely distributed in trace amounts throughout the earth's crust, occurring mainly within several minerals, such as monazite sands, thorianite, thorite and thoganite [1]. Thorium is three times more abundant than uranium in the earth's crust. Direct toxicity with thorium is low due to its stability at ambient temperatures $[2,3]$. Thorium reactors produce less waste than conventional uranium based ones. Waste solutions bearing thorium can accidently contaminate underground waters, which is considered as an environmental concern $[4,5]$. Thorium was used in a variety of applications during the last century. It has been paid more attention recently as a potential nuclear resource due to the large demand of energy. Thorium is an important alloying agent, as it offers alloys greater strength at high temperatures, making it useful in manufacturing jet engines [6]. Thorium dioxide is added to glass to increase its refractive index, producing thoriated glass for use in high-quality camera lenses [7]. ${ }^{227} \mathrm{Th}$ is an alpha-particle emitting isotope that can be used to create localized tumor-killing cancer treatments [8].

Various methods have been developed for separation and utilization of Th(IV). Such methods include biosorption [9], liquid-liquid extraction [10] and solid-phase adsorption [11, 12]. Adsorption based on carbon materials, such as activated carbon were used due to their high adsorption capacity as well as elevated thermal and radiation stability [13].

Adsorption is a low cost uptake alternative, which is simple and effective. It is obvious that utilizing adsorbents in metal recovery offers more advantages over liquid-liquid extraction technique. The simplicity of equipment and overall operation and the possibility of regenerating the solid adsorbent is a striking feature of the process. Cost is an important parameter for comparing the adsorbent materials. However, the expense of utilizing individual adsorbents varies depending on the degree of processing required and their availability. Although, the development of chelating ion exchangers is of considerable interest,

Ahmad A. Ahmad, zarginah@gmail.com | ${ }^{1}$ Nuclear Materials Authority, P.O. Box 530, El Maadi, Cairo, Egypt.

SN Applied Sciences (2019) 1:974 | https://doi.org/10.1007/s42452-019-1006-2

Received: 20 May 2019 / Accepted: 29 July 2019 / Published online: 3 August 2019

SN Applied Sciences

a SPRINGer Nature journal 
there are still many difficulties related to their preparation and cost. Due to such difficulties, the concept of using solvent impregnated sorbents has been widely utilized and developed [14, 15].

Activated charcoals possess high degree of surface reactivity due to the favorable pore size distribution, which makes their surface accessible and enhances their adsorption rate without sacrificing their mechanical strength [16]. Due to such advantages, activated carbon materials have found their way in many industrial separation and purification applications, such as the removal of different contaminants from water supplies [17].

The concern of this investigation is to introduce activated carbon modified with TPPO as an effective adsorbent for thorium ions.

\section{Experimental}

\subsection{Materials}

All the chemicals and reagents used in this work are of the analytical grade. Thorium stock solution was prepared by dissolving $2.38 \mathrm{~g}$ of Th $\left(\mathrm{NO}_{3}\right)_{4} \cdot 4 \mathrm{H}_{2} \mathrm{O}$ in $1000 \mathrm{~mL}$ of doubledistilled water to prepare $1000 \mathrm{mg} / \mathrm{L}$ stock solution, that was diluted into other desired concentrations throughout the study. Thorium concentration was determined photometrically using Arsenazo III complex, [18].

\subsection{Apparatus}

Thorium, silica, alumina, $\mathrm{TiO}_{2}$, and $\mathrm{P}_{2} \mathrm{O}_{5}$ were measured spectrophotometrically using Metertech Inc, model SP-8001, UV-Visible spectrophotometer. Sodium and potassium were determined by a Sherwood flame photometer model 410 (England), using a series of chemical solutions, while $\mathrm{CaO}, \mathrm{MgO}$ and $\mathrm{Fe}_{2} \mathrm{O}_{3}^{\mathrm{T}}$ were determined by titration [19]. Trace elements were analyzed using ICP-OES.

The Fourier Transform Infrared Spectrometer (FT-IR) (Thermo Scientific - NICOLET IS10 USA) spectrometer has been used to characterize the major functional groups of AC modified with TPPO before and after adsorption of thorium. Scanning electron microscope (SEM) was used for the specification of the modified AC before and after adsorption of thorium, as well as the final obtained thorium oxide precipitate. The modified activated carbon was identified at laboratories of the Atomic Energy Authority, Anshas, Egypt using X-ray fluorescence (XRF) "JSX-3222 Element Analyzer" with automatic sample changer (JEOL) PW 1510, connected to a computer system using X-40 program for spectroscopy with a detection limit of $5.0 \mathrm{mg} / \mathrm{L}$.

\subsection{Preparation of activated carbon}

Commercial grade activated carbon was calcinated at $500{ }^{\circ} \mathrm{C}$ for $4 \mathrm{~h}$. The powder was stirred with $10 \%$ hydrochloric acid solution for $4 \mathrm{~h}$ in order to remove any adsorbed species. The residue was filtered off and washed with double distilled water to retain neutral $\mathrm{pH}$. The purified activated carbon was stirred with $10 \%$ mixture of $\left[\mathrm{Fe}_{2}\left(\mathrm{SO}_{4}\right)_{3} \cdot 5 \mathrm{H}_{2} \mathrm{O}\right.$ and $\left.\mathrm{FeSO}_{4} \cdot 7 \mathrm{H}_{2} \mathrm{O}\right]$ for $3 \mathrm{~h}$ and solid/liquid $(\mathrm{S} / \mathrm{L})$ ratio $1 / 5$ followed by a rewashing step. The oxidized product was dried in a drying oven at $110^{\circ} \mathrm{C}$ for $4 \mathrm{~h}$ to enhance the hydroxyl capacity of $A C$, and (HO-AC) was obtained [20].

\subsection{Preparation of modified activated carbon}

A series of different concentrations $(0.005-0.03 \mathrm{M})$ of triphenyl phosphine oxide (TPPO) were used to modify activated carbon by dry technique; $0.5 \mathrm{~g}$ of activated carbon was stirred with different TPPO in toluene concentrations with $\mathrm{S} / \mathrm{L}$ ratio $(1 / 10)$ for $40 \mathrm{~min}$ at room temperature till the toluene was evaporated. The modified AC was dried at room temperature.

\subsection{Preparation of Abu-Rusheid sample}

The studied sample from Abu Rusheid area (south Eastern desert, Egypt) was leached using mixture of acids $\mathrm{HF}$, $\mathrm{HNO}_{3}, \mathrm{HClO}_{4}$ and $\mathrm{HCl}$, to determine the percent of major oxides (Table 1). Trace elements $(\mathrm{mg} / \mathrm{kg}$ ) were determined using ICP-OES technique as shown in (Table 1).

\subsection{Preparation of Abu-Rusheid leach liquor}

The studied sample was subjected to thorium leaching using optimum conditions that verify the best thorium leaching efficiency (90\%), while ensuring the minimal dissolution of unwanted impurities. The optimum conditions are -200 mesh size ground sample, $3 \mathrm{M} \mathrm{H}_{2} \mathrm{SO}_{4}$ as a leaching agent, $1 / 5$ solid/liquid ratio, $200 \mathrm{rpm}$ stirring speed for $0.5 \mathrm{~h}$ at room temperature. Thorium was measured in filtered leach liquor and found to be $1800 \mathrm{mg} / \mathrm{L}$.

\subsection{Adsorption procedures}

Batch adsorption studies were conducted by stirring the solution bearing thorium with a certain amount of modified activated carbon for a period of time at constant temperature till equilibrium was achieved. In order to predict the most favorable conditions, such procedures were carried out at different $\mathrm{pH}$ values ranging from 1 to 7 , different thorium 
Table 1 Chemical composition of major oxide (wt \%) and trace elements content $(\mathrm{mg} / \mathrm{kg})$ using ICP-OES technique

\begin{tabular}{|c|c|}
\hline Major oxides & wt $\%$ \\
\hline $\mathrm{SiO}_{2}$ & 73.51 \\
\hline $\mathrm{Al}_{2} \mathrm{O}_{3}$ & 12.50 \\
\hline $\mathrm{TiO}_{2}$ & 0.12 \\
\hline $\mathrm{Fe}_{2} \mathrm{O}_{3}^{\top}$ & 5 \\
\hline $\mathrm{CaO}$ & 1.0 \\
\hline $\mathrm{MgO}$ & 0.63 \\
\hline $\mathrm{Na}_{2} \mathrm{O}$ & 0.63 \\
\hline $\mathrm{K}_{2} \mathrm{O}$ & 3.5 \\
\hline $\mathrm{P}_{2} \mathrm{O}_{5}$ & 0.12 \\
\hline L.O.I & 1.08 \\
\hline Trace elements & $(\mathrm{mg} / \mathrm{kg})$ \\
\hline Th & 10,000 \\
\hline $\mathrm{Zr}$ & 194.83 \\
\hline $\mathrm{Sr}$ & 16.28 \\
\hline $\mathrm{Cr}$ & 8.762 \\
\hline $\mathrm{Cd}$ & 3.37 \\
\hline Co & 0.58 \\
\hline $\mathrm{Cu}$ & 63.56 \\
\hline $\mathrm{Zn}$ & 1977.91 \\
\hline $\mathrm{Pb}$ & 61.86 \\
\hline $\mathrm{Li}$ & 1146.09 \\
\hline $\mathrm{Mn}$ & 210.72 \\
\hline Mo & 1.79 \\
\hline $\mathrm{Ni}$ & 5.36 \\
\hline $\mathrm{Tl}$ & 5.67 \\
\hline V & 1.55 \\
\hline $\mathrm{Ba}$ & 63.49 \\
\hline As & 1.04 \\
\hline $\mathrm{Sb}$ & 6.38 \\
\hline Sn & 20.02 \\
\hline$B$ & 12.81 \\
\hline
\end{tabular}

concentrations varying from 50 to $1000 \mathrm{mg} / \mathrm{L}$, different time intervals ranging from 10 to $90 \mathrm{~min}$., different temperatures and different adsorbent doses while keeping the agitation speed constant at $200 \mathrm{rpm}$. The adsorbent was separated thorium was measured in the filtrate. The thorium uptake capacity $\left(\mathrm{q}_{\mathrm{e}}, \mathrm{mg} / \mathrm{g}\right)$, adsorption efficiency $(\mathrm{E} \%)$ and distribution coefficient $\left(K_{d}\right)$ were calculated from the following equations:

$\mathrm{q}_{\mathrm{e}}=\left(\mathrm{C}_{\mathrm{o}}-\mathrm{C}_{\mathrm{e}}\right) \times \mathrm{v} / \mathrm{m}$

$\mathrm{E}(\%)=100\left(\mathrm{C}_{\mathrm{o}}-\mathrm{C}_{\mathrm{e}}\right) / \mathrm{C}_{\mathrm{o}}$

$\mathrm{K}_{\mathrm{d}}=\left[\left(\mathrm{C}_{\mathrm{o}}-\mathrm{C}_{\mathrm{e}}\right) / \mathrm{C}_{\mathrm{e}}\right] \times \mathrm{V} / \mathrm{m}$ where $C_{o}$ and $C_{e}$ are the initial and equilibrium thorium (IV) concentrations ( $\mathrm{mg} / \mathrm{L}$ ), respectively, $\mathrm{V}$ is the volume of the aqueous solution $(\mathrm{L})$ and $\mathrm{m}$ is the dry resin weight $(\mathrm{g})$.

\section{Results and discussions}

\subsection{Characterization of the synthesized modified activated carbon}

\subsubsection{Fourier-transform infrared spectrometer characterization}

FTIR is a useful tool to identify molecular functional groups [21]. FTIR model Thermo Scientific Nicolet IS10 instrument via the KBR pressed disc method was used in a range starting from 400 to $4000 \mathrm{~cm}^{-1}$ wave numbers. The (FTIR) results of AC modified with TPPO before and after adsorption of thorium are given in (Fig. 1A, $B)$. The obtained (FTIR) results of prepared AC modified with TPPO showed peaks at 3852.96, 3728.69, 3703.62, $3625.37,3601.97$ and $3352.23 \mathrm{~cm}^{-1}$ corresponding to AC-OH stretching. The peaks at 1735.42 to $1654.30 \mathrm{~cm}^{-1}$ corresponding to mono substituted aromatic. The bands 1576.70 and $1503.74 \mathrm{~cm}^{-1}$ are related to $C=C$ ring stretching. While, the bands 1483.25 and $1413.39 \mathrm{~cm}^{-1}$ are attributed to asymmetric $\mathrm{CH}_{3}$ stretching. Two bands 1357.12 , and $1332.67 \mathrm{~cm}^{-1}$ are related to $(\mathrm{Ar})_{3}-\mathrm{P}=\mathrm{O}$ stretching. One peak at $1167.16 \mathrm{~cm}^{-1}$ is related to $\mathrm{P}=0$ aromatic stretching. The peaks at $799.93,720.53,681.02$, $668.88,657.67$ and $617.95 \mathrm{~cm}^{-1}$ are corresponding to out of plane $\mathrm{C}-\mathrm{H}$ aromatic bending. Finally, peaks at 539.64 , $511.30,473.13$, and $463.45 \mathrm{~cm}^{-1}$ are attributed to hydrogen bond out of plane $\mathrm{OH}$ (Fig. 1A). While, after adsorption of thorium the peaks at 1413.39, 1357.12, 720.53 and $617.95 \mathrm{~cm}^{-1}$ disappeared and new peak appeared at $1384.10 \mathrm{~cm}^{-1}$. Most bands are shifted which indicated the adsorption of thorium onto AC modified with TPPO (Fig. 1B).

\subsubsection{Scanning electron microscope (SEM)}

SEM and EDX of the AC modified with TPPO before and after adsorption of thorium were shown in (Fig. 2a, b). Results show the presence of thorium after adsorption onto the modified AC surface.

\subsubsection{X-ray fluorescence (XRF)}

Both the synthesized and loaded modified AC were identified by X-ray fluorescence (XRF) as shown in (Fig. 3a, b). The results show that thorium was 


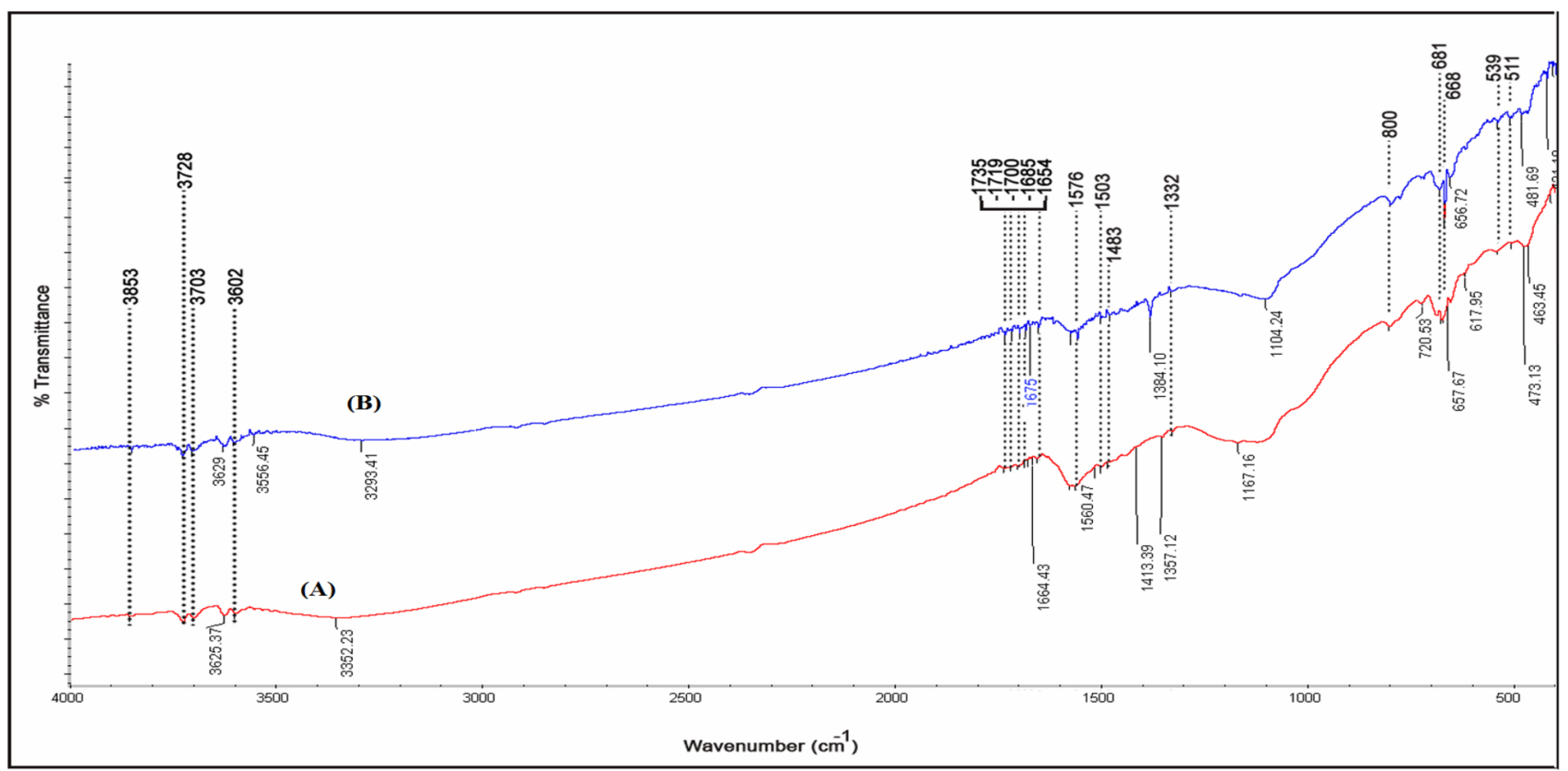

Fig. 1 FTIR chart of the AC modified with TPPO before (A) and after (B) the adsorption of thorium
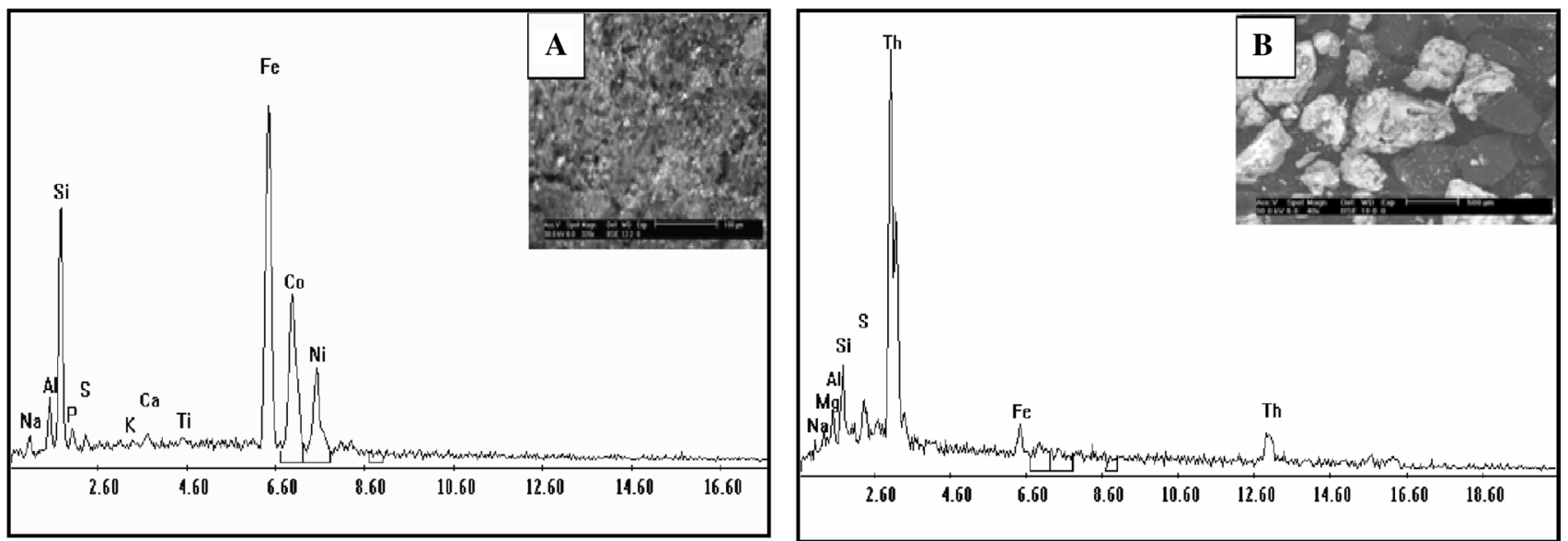

Fig. 2 SEM and EDX of AC modified with TPPO before (a) and after (b) the adsorption of thorium

successfully adsorbed onto the surface of the modified $\mathrm{AC}$.

\subsubsection{Effect of $\mathrm{pH}$}

Proton availability is important for metal adsorption nearly by all adsorbents. The $\mathrm{pH}$ directly influences the aqueous chemistry of thorium and the properties of the sorbent's active sites [22]. The retention of thorium(IV) on the prepared modified $\mathrm{AC}$ was studied in the $\mathrm{pH}$ range from 1 to 7 using $100 \mathrm{~mL}$ thorium solution assaying $400 \mathrm{mg} / \mathrm{L}, 0.5 \mathrm{~g}$ modified AC and 200 rpm stirring speed for 40 min at room temp. The obtained results indicated that thorium(IV) adsorption efficiency increases with increasing the $\mathrm{pH}$ from 1 to 3.6 , where it reaches a maximum of $89 \%$ at $\mathrm{pH}$ 3.6 then adsorption efficiency decreases with increasing $\mathrm{pH}$ up to 7 (Fig. 4). This is due to electrostatic repulsion of the protonated active sites with the positively charged of thorium ion species.

From the obtained results, it is clear that the efficiency of thorium adsorption depends on $\mathrm{pH}$ dependent and that maximum adsorption occurs at $\mathrm{pH} 3.6$ due to surface properties of the modified $A C$ as well as the variation of thorium complex species distribution at different $\mathrm{pH}$ values [23]. The dominant thorium species at $\mathrm{pH} 3.6$ are $\mathrm{Th}(\mathrm{OH})_{2}^{2+}$ or $\mathrm{Th}(\mathrm{OH})^{3+}$. The adsorption percent was low 
Fig. 3 XRF analysis of the AC modified with TPPO before (a) and after (b) the adsorption of thorium
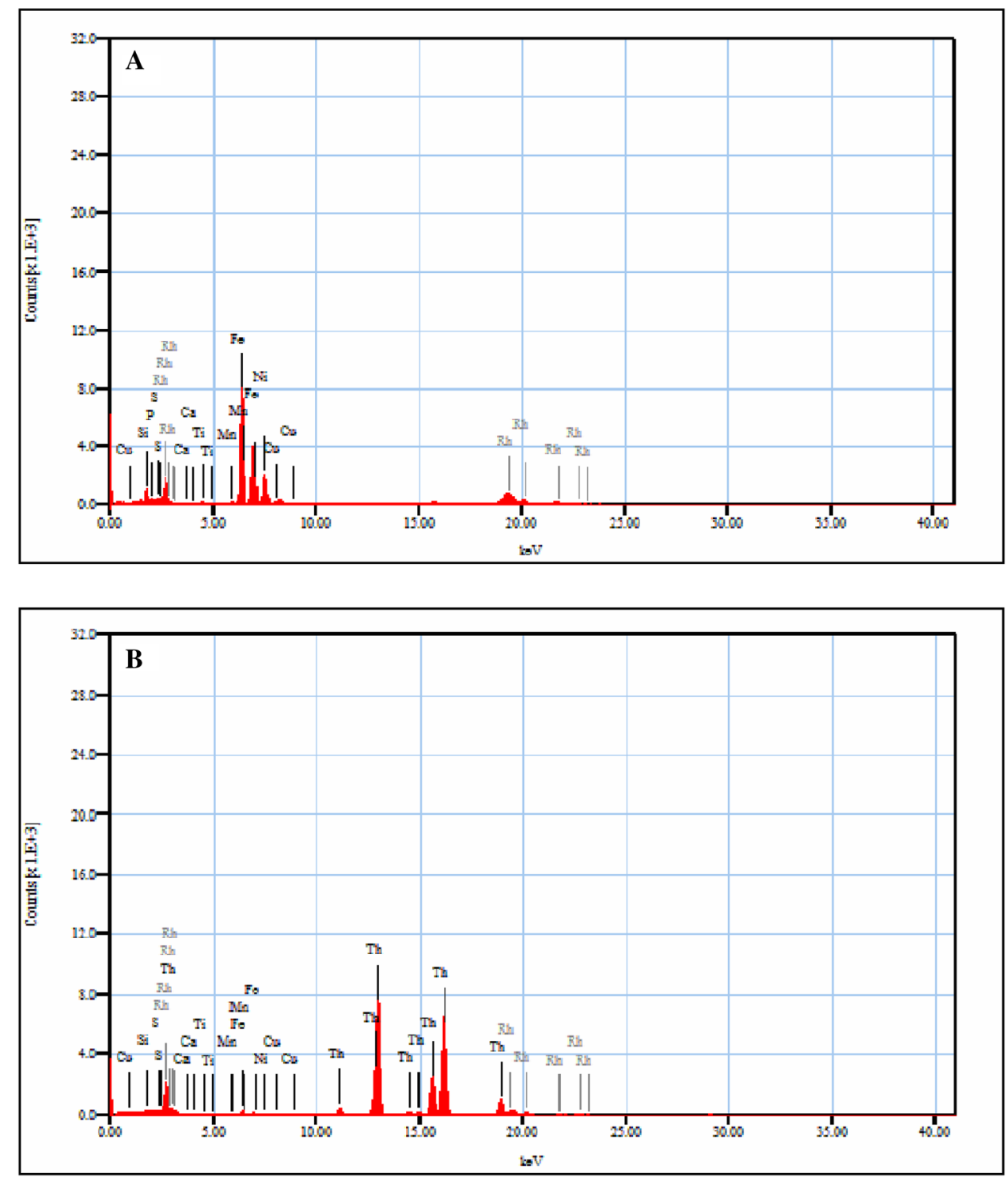

at $\mathrm{pH}$ values below 3 , due to the protonation of residual oxygen-containing groups on the modified $A C$ as well as the competition between $\mathrm{H}^{+}$and $\mathrm{Th}^{4+}$ ions for the same adsorption sites [24]. However, on increasing the $\mathrm{pH}$ beyond 4, hydrolytic precipitation of thorium ions results in declining the adsorption capacity. At $\mathrm{pH}>4$, thorium precipitates as $\mathrm{Th}(\mathrm{OH})_{4}$. At higher $\mathrm{pH}$ values, monomer and polynuclear species of thorium may include $\mathrm{Th}(\mathrm{OH})^{3+}$, $\mathrm{Th}(\mathrm{OH})_{3}^{+}, \mathrm{Th}(\mathrm{OH})_{2}^{2+}, \mathrm{Th}_{2}(\mathrm{OH})_{2}^{6+}, \mathrm{Th}_{2}(\mathrm{OH})_{4}^{4+}, \mathrm{Th}_{4}(\mathrm{OH})_{8}^{8+}$, and $\mathrm{Th}_{6}(\mathrm{OH})_{14}^{8+}[25]$.

\subsubsection{Effect of contact time}

The effect of contact time was studied while keeping other parameters affecting the adsorption constant. Time was varied from 10 to $90 \mathrm{~min}$. It was found that thorium adsorption efficiency increased with increasing the contact time (Fig. 5). The adsorption efficiency of thorium increased from $55 \%$ at $10 \mathrm{~min}$ to $89 \%$ at $40 \mathrm{~min}$. Sorption reached apparent equilibrium after about $40 \mathrm{~min}$. No significant change in thorium adsorption efficiency was noticed beyond that time, revealing that a state of equilibrium was reached. This indicates that adsorption occurred as monolayer on the surface of the adsorbent. When all the adsorption sites were saturated, the increase in metal ions uptake was seized [26]. Further increase in time encountered a decrease in metal uptake due to intra-particle diffusion processes dominating over adsorption [27].

\subsubsection{Effect of triphenyl phosphine oxide (TPPO) concentration}

A series of experiments were performed using $0.5 \mathrm{~g}$ of activated carbon stirred for 40 min with different 
Fig. 4 Effect of $\mathrm{pH}$ on $\mathrm{Th}^{4+}$ adsorption efficiency using AC modified with TPPO. Adsorption conditions: $400 \mathrm{mg} / \mathrm{L}$ thorium concentration, $40 \mathrm{~min}$ contact time, room temperature, $100 \mathrm{~mL}$ of thorium solution and $0.5 \mathrm{~g}$ modified $\mathrm{AC}$ with TPPO

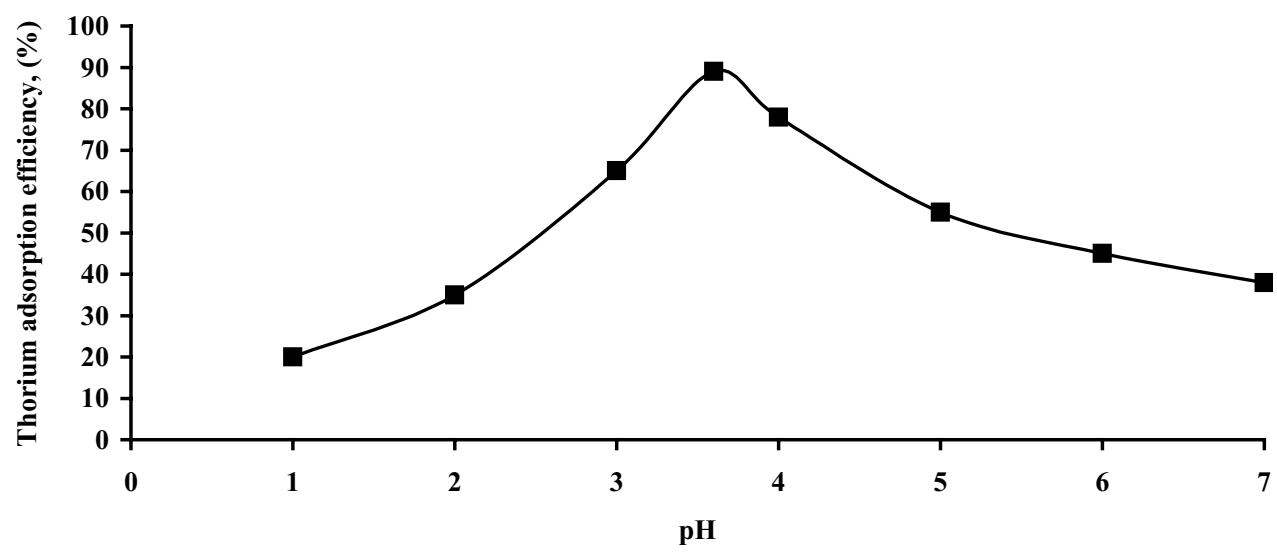

Fig. 5 Effect of contact time (min) on $\mathrm{Th}^{4+}$ adsorption efficiency using AC modified with TPPO. Adsorption conditions: $400 \mathrm{mg} / \mathrm{L}$ thorium concentration, $\mathrm{pH} 3.6$, room temperature, $100 \mathrm{~mL}$ of thorium solution and $0.5 \mathrm{~g}$ modified AC with TPPO

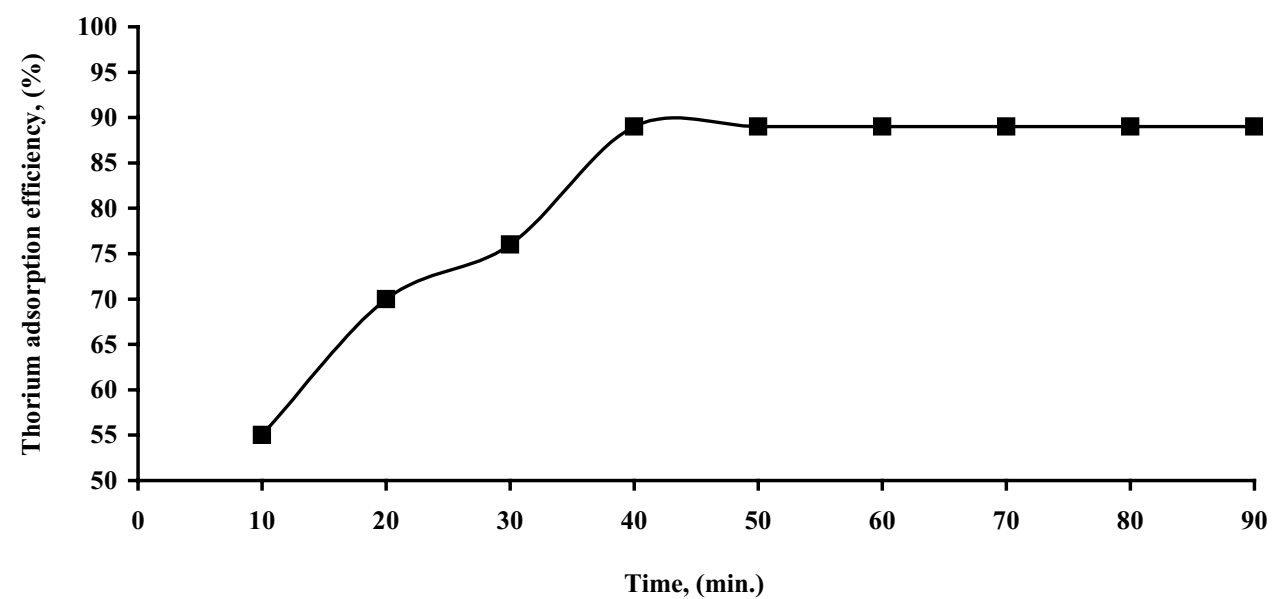

concentrations of ( 0.005 to $0.03 \mathrm{M})$ TPPO in toluene with $\mathrm{S} / \mathrm{L}$ ratio $(1 / 10)$ at room temperature (Fig. 6$)$. The obtained results indicate that thorium adsorption efficiency increased with increasing the concentration of (TPPO) until reaching maximum value at $0.02 \mathrm{M} \mathrm{TPPO}$.

\subsubsection{Effect of initial thorium concentration}

A series of prepared $100 \mathrm{~mL}$ solutions of different initial thorium concentrations ranging from 50 to $1000 \mathrm{mg} / \mathrm{L}$ were mixed with $0.5 \mathrm{~g}$ of modified $\mathrm{AC}$ at $\mathrm{pH} 3.6$ and $200 \mathrm{rpm}$ stirring speed for $40 \mathrm{~min}$ at room temperature. The effect of initial thorium concentration is expressed in terms of uptake capacity $\left(\mathrm{q}_{\mathrm{e}}\right.$ ) (Fig. 7). Accordingly, $400 \mathrm{mg} / \mathrm{L}$ of thorium was found optimum to yield maximum uptake capacity, $\left(\mathrm{q}_{\mathrm{e}}=71.2 \mathrm{mg} / \mathrm{g}\right.$ for $\mathrm{AC}$ modified with TPPO).

Increasing thorium concentration results in higher molecular competition on the available surface active sites on the surface of the adsorbent, thus, leading to a decrease in the overall adsorption efficiency [28].

\subsubsection{Effect of temperature}

Several experiments were performed at temperatures ranging from 25 to $70{ }^{\circ} \mathrm{C}$. Other parameters were fixed at $400 \mathrm{mg} / \mathrm{L}$ thorium, $\mathrm{pH} 3.6$ and $200 \mathrm{rpm}$ stirring speed for $40 \mathrm{~min}$. The maximum adsorption efficiency was $89 \%$ at $25^{\circ} \mathrm{C}$ and dropped down to $50 \%$ at $70{ }^{\circ} \mathrm{C}$, (Fig. 8). Such results show that room temperature is the most favorable temperature for thorium adsorption by the modified AC.

\subsubsection{Effect of modified AC dose}

Different amounts of modified AC ranging from 0.1 to $1 \mathrm{~g}$ were mixed with $100 \mathrm{~mL}$ of thorium solution at optimum conditions. Thorium adsorption efficiency increased from $55 \%$ with $0.1 \mathrm{~g}$ to reach $89 \%$ with $0.5 \mathrm{~g}$, (Fig. 9). Furthermore, the adsorption efficiency decreased by increasing the adsorbent dose. At low adsorbent doses, all the active sites are available for thorium adsorption. On the other hand, at higher adsorbent amounts, the crowdedness of thorium ions will lead to difficulty to fill the remaining sites due to electrostatic repulsion between thorium ions [29, 30]. 
Fig. 6 Effect of TPPO concentration on $\mathrm{Th}^{4+}$ adsorption efficiency using AC. Adsorption conditions: $\mathrm{pH} 3.6,40$ min contact time, room temperature, $100 \mathrm{~mL}$ of thorium solution and $0.5 \mathrm{~g}$ of $\mathrm{AC}$

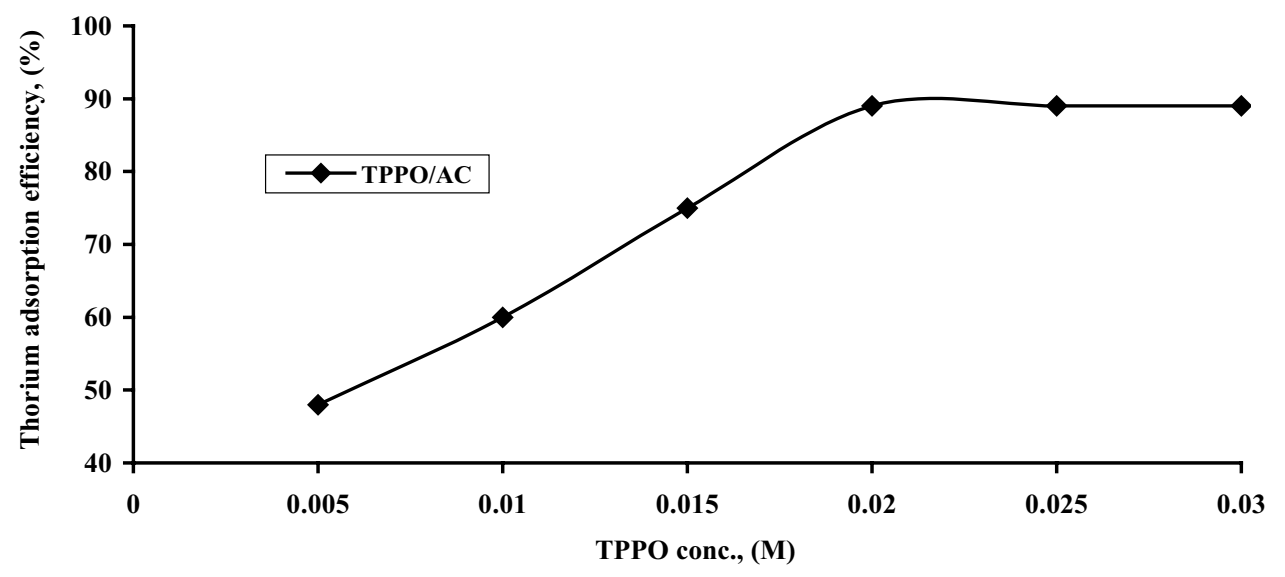

Fig. 7 Effect of initial thorium concentration $(\mathrm{mg} / \mathrm{L})$ on the uptake capacity of AC modified with TPPO. Adsorption conditions: $\mathrm{pH}$ 3.6, 40 min. contact time, room temperature, $100 \mathrm{~mL}$ of thorium solution and $0.5 \mathrm{~g}$ of modified $\mathrm{AC}$ with TPPO

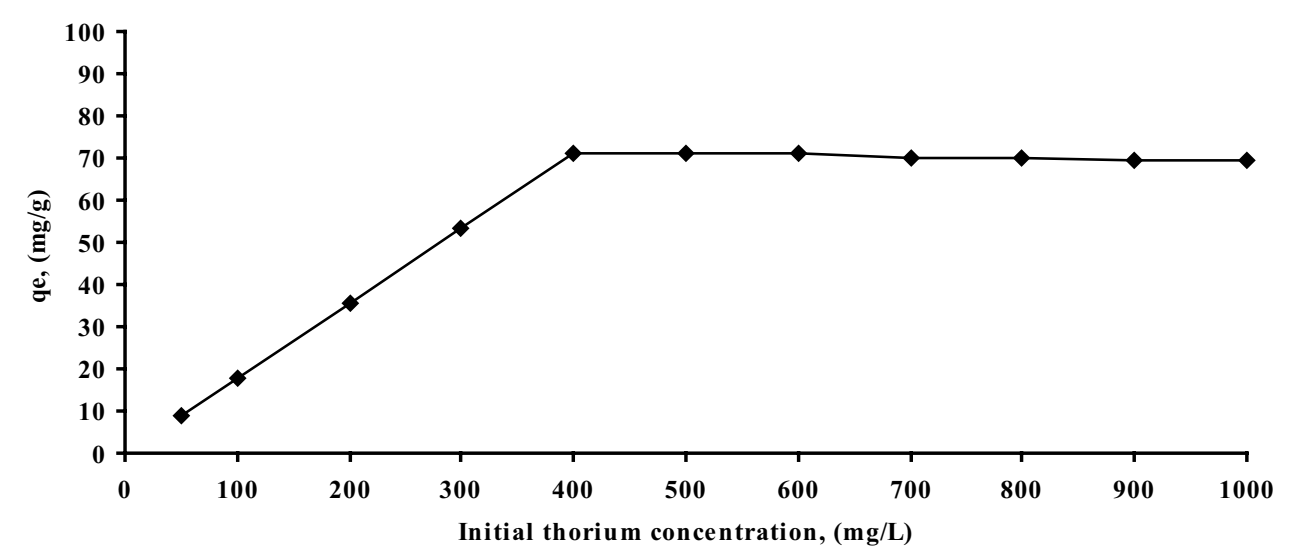

Fig. 8 Effect of temperature on $\mathrm{Th}^{4+}$ adsorption efficiency by AC modified with TPPO. Adsorption conditions: $400 \mathrm{mg} / \mathrm{L}$ thorium concentration, 40 min contact time, $\mathrm{pH}$ 3.6, $100 \mathrm{~mL}$ of thorium solution and $0.5 \mathrm{~g}$ of modified $\mathrm{AC}$ with TPPO

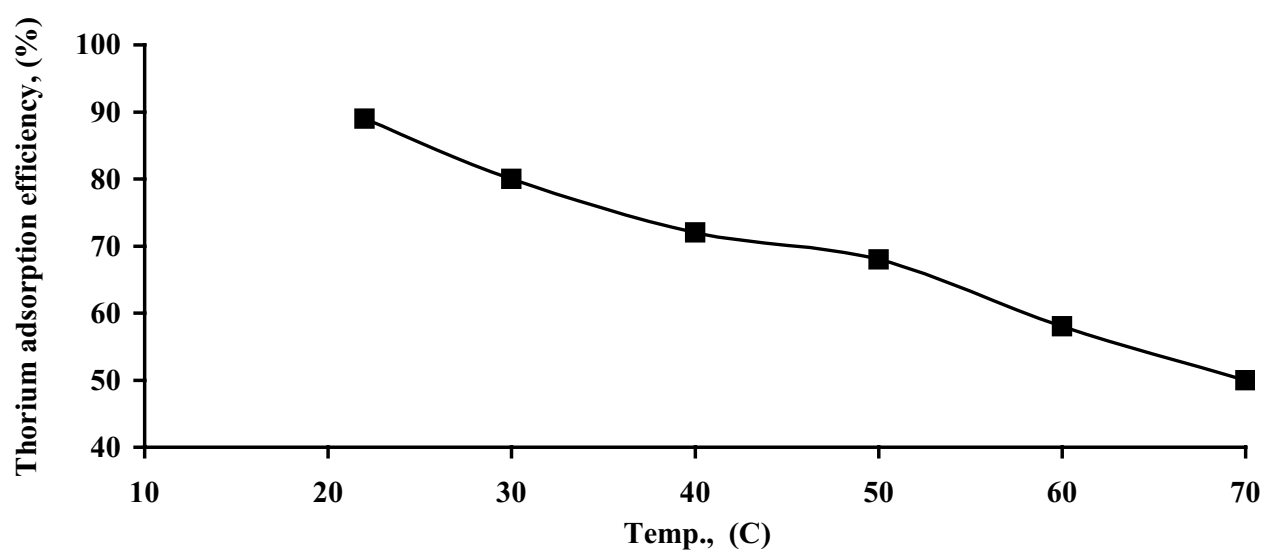

\subsubsection{Desorption and regeneration of modified activated carbon}

Desorption enhances the economic value of the overall adsorption process [31]. Three mineral acids $\left(\mathrm{H}_{2} \mathrm{SO}_{4}, \mathrm{HNO}_{3}\right.$, $\mathrm{HCl}$ ) having the same concentration (1 $\mathrm{M})$ were examined using $100 \mathrm{~mL}$ of diluted acid solution to elute thorium loaded on to $0.5 \mathrm{~g}$ modified AC for $30 \mathrm{~min}$ at room temperature. From (Table 2), sulfuric acid was found the most suitable acid to elute loaded thorium.
In order to determine the optimum $\mathrm{H}_{2} \mathrm{SO}_{4}$ concentration, a series of $100 \mathrm{~mL}$ of different acid concentration solutions ranging from 0.1 to $1.0 \mathrm{M}$ were mixed with $0.5 \mathrm{~g}$ of modified $A C$ at room temperature for $40 \mathrm{~min}$. Table 2 shows that Th(IV) elution efficiency increases from $42 \%$ with $0.1 \mathrm{M} \mathrm{H}_{2} \mathrm{SO}_{4}$ till $93 \%$ at $0.5 \mathrm{M}$. Further increase in sulfuric acid concentration shows no enhancement to the elution efficiency. The optimum sulfuric acid concentration sufficient to elute Th(IV) efficiently was $0.5 \mathrm{M} \mathrm{H}_{2} \mathrm{SO}_{4}$. 
Fig. 9 Effect of modified AC dose on $\mathrm{Th}^{4+}$ adsorption efficiency. Adsorption conditions: $400 \mathrm{mg} / \mathrm{L}$ thorium concentration, 40 min. contact time, room temperature, $\mathrm{pH} 3.6$ and $100 \mathrm{~mL}$ of thorium solution

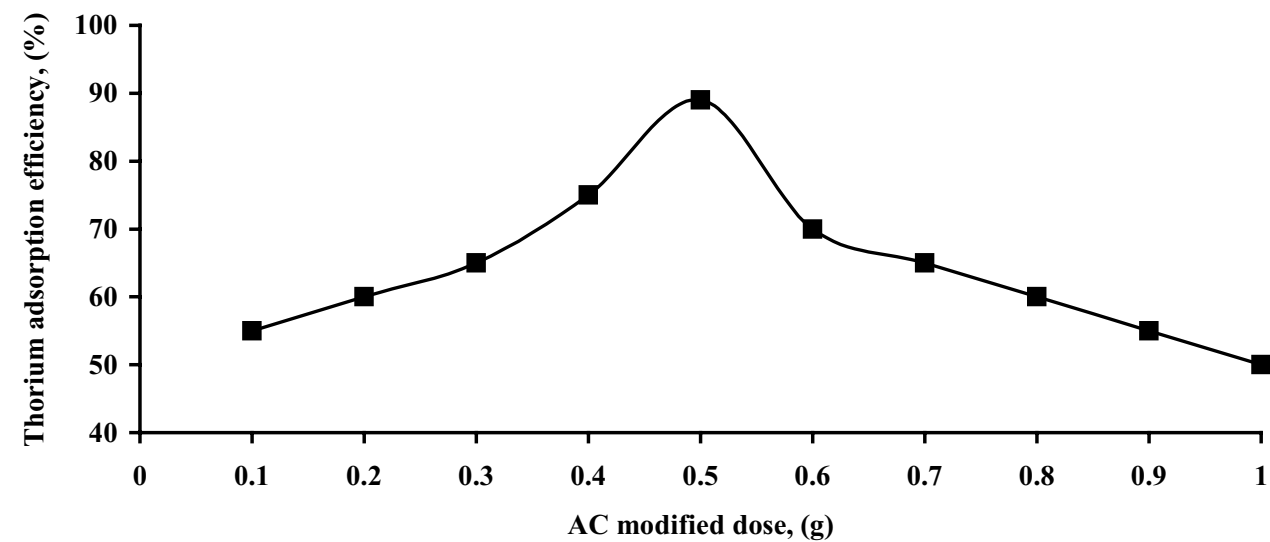

In the current study, both Langmuir and Freundlich iso-

Table 2 Effect of different eluting agents with emphasis on $\mathrm{H}_{2} \mathrm{SO}_{4}$ concentration on $\mathrm{Th}^{4+}$ elution efficiency (\%)

\begin{tabular}{llll}
\hline Eluting agents (1 M) & $\mathrm{HNO}_{3}$ & $\mathrm{H}_{2} \mathrm{SO}_{4}$ & $\mathrm{HCl}$ \\
\hline Thorium elution efficiency (\%) & 75 & 93 & 56 \\
\hline $\mathrm{H}_{2} \mathrm{SO}_{4}$ conc. (M) & & $\begin{array}{l}\text { Thorium elution } \\
\text { efficiency (\%) }\end{array}$ \\
\hline 0.1 & & 42 \\
0.2 & 58 \\
0.3 & 65 & \\
0.4 & 75 & \\
0.5 & 93 & \\
0.6 & 93 & \\
0.75 & & 93 & \\
1 & & 93 & \\
\hline
\end{tabular}

Regeneration is an important feature of the studied adsorbent in order to ensure its economic applicability and reuse. The adsorption-desorption cycle was repeated five times with the same loaded adsorbent using $0.5 \mathrm{M}$ $\mathrm{H}_{2} \mathrm{SO}_{4}$. Table 3 shows that the adsorption capacity of $\mathrm{Th}(\mathrm{IV})$ decreased slightly after 5 regeneration cycles from 71.2 to $68 \mathrm{mg} / \mathrm{g}$, while the adsorption efficiency decreased from 89 to $85 \%$. After the fifth cycle, the adsorption efficiency decreased sharply to $50 \%$. Thus, the studied modified AC possesses excellent reusability features.

\subsubsection{Adsorption equilibrium studies}

Adsorption isotherms can clearly characterize the interaction pathway of Th(IV) with the modified AC adsorbent. Equilibrium studies are generally used for both the design of sorption process and understanding the sorption mechanism. Thorium ions can be adsorbed onto the surface of a solid support by several mechanisms. The operative mechanism depends on the nature of sorption sites, surface properties, affinities of the sorbent, the type of the sorbate and the bulk properties of the aqueous solution [32]. therm models were used to correlate experimental data at the determined optimum conditions. Sorption experiments were conducted by mixing $10 \mathrm{~mL}$ of solution of an initial thorium concentration $400 \mathrm{mg} / \mathrm{L}$ with $0.5 \mathrm{~g}$ of the modified $A C$ at $\mathrm{pH} 3.6$ and $200 \mathrm{rpm}$ agitation speed for $40 \mathrm{~min}$ at room temperature.

Langmuir adsorption model assumes that adsorption occurs mainly as a saturated monolayer of adsorbate on the surface of the adsorbent. This model assumes too that the energy of adsorption is constant and there is no transmigration of the adsorbed molecules on the adsorbent surface [33]. Langmuir isotherm model can be expressed in the following form:

$\frac{C_{e}}{q_{e}}=\frac{1}{b q_{\max }}+\frac{C_{e}}{q_{\max }}$

where $C_{e}$ is concentration of thorium in solution at equilibrium (mg/L), $\mathrm{q}_{\mathrm{e}}$ is the amount of thorium adsorbed per weight unit of adsorbent at equilibrium ( $\mathrm{mg} / \mathrm{g}), q_{\max }$ is the saturated monolayer maximum adsorption capacity $(\mathrm{mg} / \mathrm{g})$ and $\mathrm{b}$ is Langmuir constant $(\mathrm{L} / \mathrm{mg})$. The linear plots of $C_{e} / q_{e}$ versus $C_{e}$ are shown in (Fig. 10). The maximum calculated adsorption capacity $\left(\mathrm{q}_{\max }\right)$ was close to experimental data and the correlation coefficient was 0.9977 at room temperature, (Table 4). The value of saturation capacity determined from Langmuir isotherm model was $71.94 \mathrm{mg} / \mathrm{g}$ at room temperature which is near to the experimental value of $71.2 \mathrm{mg} / \mathrm{g}$. The tested modified AC showed high sorption capacity compared to other adsorbents [34-40]. From Langmuir assumptions, thorium uptake has occurred on a homogeneous surface as a monolayer and all the metal binding sites are energetically

The dimensionless constant called separation factor; $R_{L}$, can be used to predict whether the sorption system is favorable or unfavorable. This parameter can be calculated from the following equation [42]: the same [41]. 
Table 3 Five cycles of $\mathrm{Th}^{4+}$ adsorption-desorption with $0.5 \mathrm{M}$ $\mathrm{H}_{2} \mathrm{SO}_{4}$ acid

\begin{tabular}{llll}
\hline Cycle & Adsorption (\%) & $\mathrm{q}_{\mathrm{e}}(\mathrm{mg} / \mathrm{g})$ & $\begin{array}{l}\text { Desorp- } \\
\text { tion (\%) }\end{array}$ \\
\hline 1 & 89 & 71.2 & 93 \\
2 & 88 & 70.4 & 91 \\
3 & 87 & 69.6 & 90 \\
4 & 86 & 68.8 & 89 \\
5 & 85 & 68 & 88 \\
\hline
\end{tabular}

Adsorption conditions $400 \mathrm{mg} / \mathrm{L}$ thorium concentration, $40 \mathrm{~min}$ contact time, room temperature, $\mathrm{pH} 3.6,100 \mathrm{~mL}$ of thorium solution and $0.5 \mathrm{~g}$ of modified AC with TPPO

$\mathrm{R}_{\mathrm{L}}=1 / 1+\mathrm{bC}_{\mathrm{o}}$

where $b$ is the Langmuir constant and $C_{0}$ is the initial Th(IV) concentration ( $\mathrm{mg} / \mathrm{L}$ ). The value of $R_{L}$ indicates the nature of the isotherm; if $\left(R_{L}=0\right)$ then irreversible, if $\left(0<R_{L}<1\right)$ then favorable and if $\left(R_{L}>1\right)$ then unfavorable. The obtained data shows that the values of $R_{L}$ are $>1$, indicating a favorable sorption process under the conditions applied.

On the other hand, The Freundlich isotherm model assumes that the adsorption process is carried out on a surface of adsorbent with a heterogeneous energetic distribution of active sites, accompanied by interactions between adsorbed molecules [43]. The Freundlich isotherm model is represented by the equation:

$\ln q_{e}=\ln K_{F}+\frac{1}{n} \ln C_{e}$

where $C_{e}$ is the equilibrium concentration of thorium in the solution (mg/L), $q_{e}$ is the amount of thorium adsorbed per weight unit of modified $A C$ at equilibrium $(\mathrm{mg} / \mathrm{g}), \mathrm{K}_{\mathrm{f}}$ is the adsorption capacity $(\mathrm{mg} / \mathrm{g})$ and $1 / \mathrm{n}$ is the Freundlich constant related to the intensity of adsorption $(\mathrm{L} / \mathrm{mg})$.

The Freundlich constants $\mathrm{K}_{\mathrm{f}}$ and $1 / \mathrm{n}$ are calculated from the slope and intercept of the $\log q_{e}$ versus $\log C_{e}$
Table 4 Adsorption isotherms of thorium by AC modified with TPPO

\begin{tabular}{lll}
\hline $\begin{array}{l}\text { Adsorption isotherm } \\
\text { models }\end{array}$ & Parameters & $298 \mathrm{~K}$ \\
\hline Langmuir isotherm & Equation & $\mathrm{Y}=0.0139 \mathrm{x}+0.2218$ \\
& $\mathrm{q}_{\max }(\mathrm{mg} / \mathrm{g})$ & 71.94 \\
& $\mathrm{~b}(\mathrm{~L} / \mathrm{mg})$ & 0.062 \\
& $\mathrm{R}^{2}$ & 0.9977 \\
Freundlich isotherm & Equation & $\mathrm{Y}=0.3425 \mathrm{x}+1.0031$ \\
& $\mathrm{k}_{\mathrm{f}}(\mathrm{mg} / \mathrm{g})$ & 10.07 \\
& $1 / \mathrm{n}(\mathrm{mg} \min / \mathrm{g})$ & 0.3425 \\
& $\mathrm{R}^{2}$ & 0.7099 \\
\hline
\end{tabular}

Adsorption conditions $400 \mathrm{mg} / \mathrm{L}$ thorium concentration, $40 \mathrm{~min}$ contact time, room temperature, $0.5 \mathrm{~g}$ modified AC TPPO dose, $\mathrm{pH} 3.6$ and $100 \mathrm{~mL}$ of thorium solution

plots (Fig. 11). The adsorption parameters are shown in (Table 4). The value of $K_{f}(\mathrm{mg} / \mathrm{g})$ is lower than the experimental capacity of Th(IV) on modified AC at room temperature. From the obtained data, the calculated by Freundlich isotherm model does not fit with experimental data.

\subsubsection{Sorption kinetics studies}

Kinetic studies are helpful for the prediction of adsorption rate and gives important information for designing and modeling extraction processes. Two kinetic models including pseudo-first order and pseudo-second order diffusion models were applied to analyze the kinetics of the sorption process. Thorium sorption kinetics was studied at $400 \mathrm{mg} / \mathrm{L}$ concentration, $\mathrm{pH} 3.6$ and stirring speed of $200 \mathrm{rpm}$ at room temperature.

The linear form of pseudo-first order kinetic model can be represented by following equation [44]:

$\log \left(\mathrm{q}_{\mathrm{e}}-\mathrm{q}_{\mathrm{t}}\right)=\log \mathrm{q}_{\mathrm{e}}-\left(\mathrm{K}_{1} / 2.303\right) \mathrm{t}$

where $q_{t}$ and $q_{e}$ are the amounts of thorium ions adsorbed in $(\mathrm{mg} / \mathrm{g})$ at time $\mathrm{t}(\mathrm{min})$ at equilibrium. The constant $\mathrm{k}_{1}$ is
Fig. 10 Langmuir isotherm model of $\mathrm{Th}^{4+}$ adsorption by the AC modified with TPPO

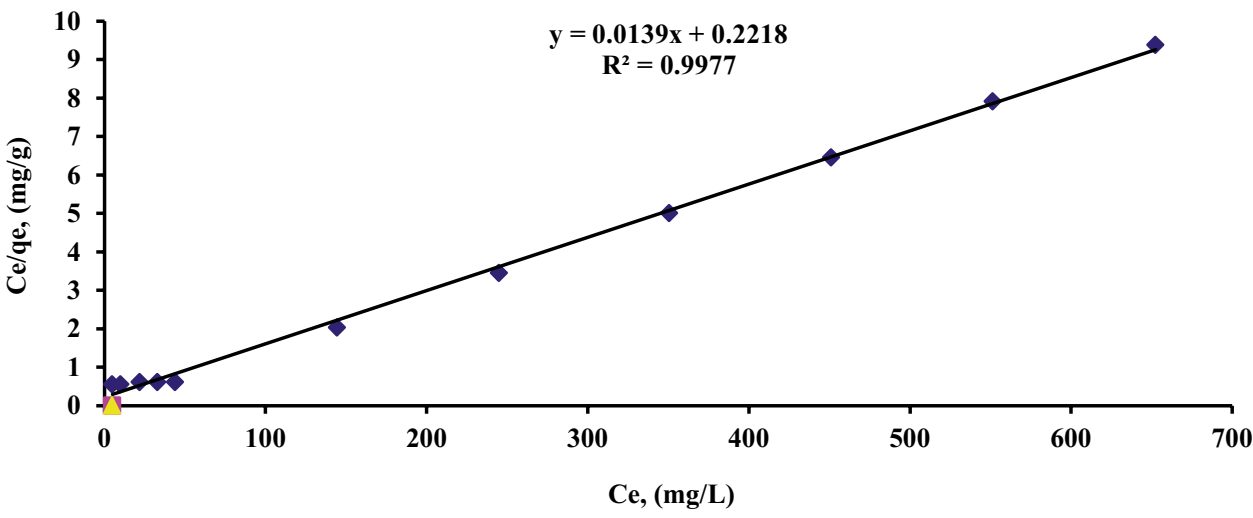

SN Applied Sciences 
Fig. 11 Freundlich isotherm model of $\mathrm{Th}^{4+}$ adsorption by AC modified with TPPO
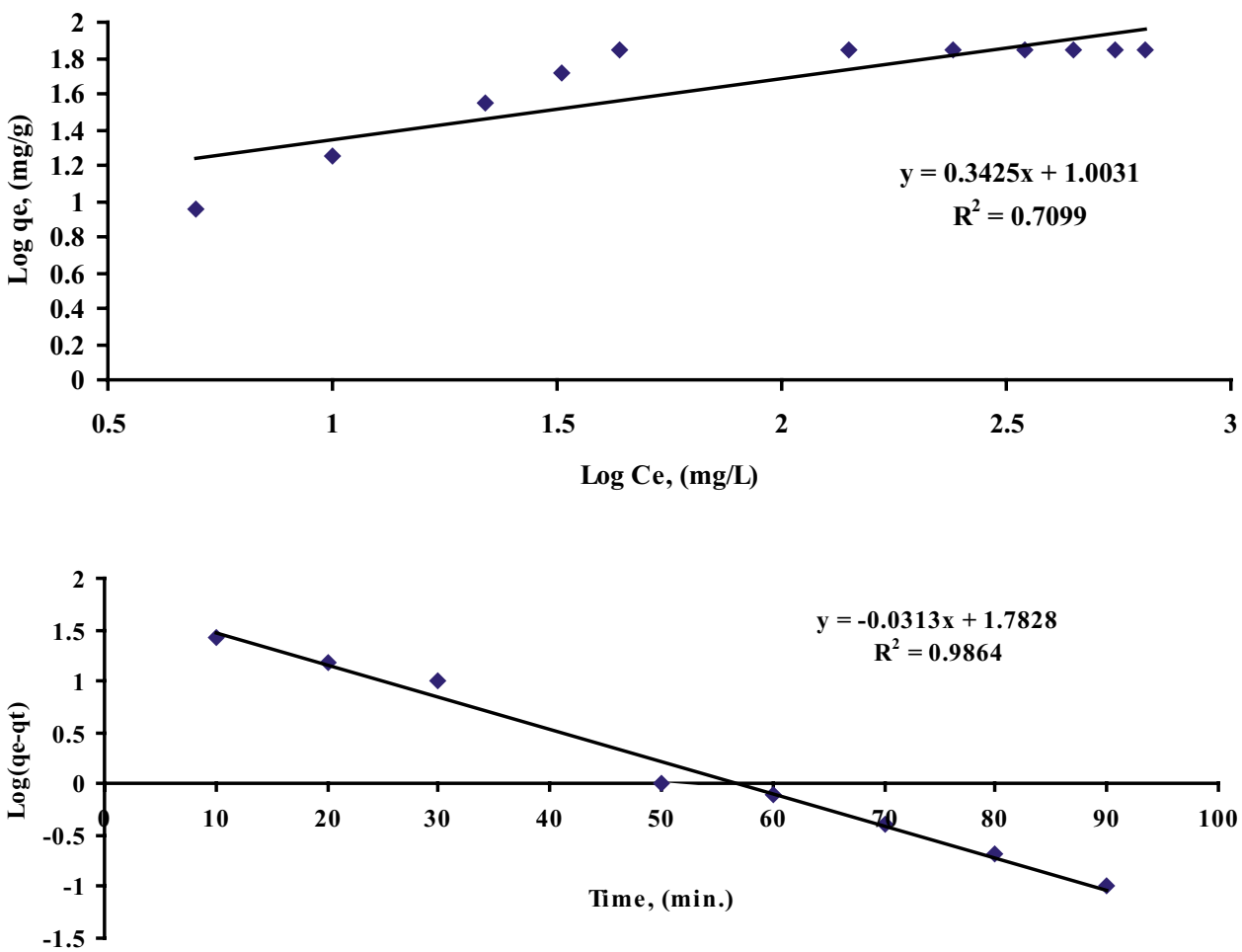

Fig. 12 Pseudo first order adsorption model of $\mathrm{Th}^{4+}$ by AC modified with TPPO
Table 5 Sorption kinetics of thorium by AC modified with TPPO

\begin{tabular}{llc}
\hline Kinetic of sorption & Parameters & $298 \mathrm{~K}$ \\
\hline Pseudo first order & $\mathrm{q}_{\mathrm{e}}(\mathrm{mg} / \mathrm{g})$ & 60.64 \\
& $\mathrm{~K}_{1}\left(\mathrm{~min}^{-1}\right)$ & 0.072 \\
Pseudo second order & $\mathrm{R}^{2}$ & 0.9864 \\
& $\mathrm{q}_{\mathrm{e}}(\mathrm{mg} / \mathrm{g})$ & 77.51 \\
& $\mathrm{~K}_{2}(\mathrm{~g} / \mathrm{mg} \mathrm{min})$ & 0.00193 \\
& $\mathrm{R}^{2}$ & 0.9968 \\
\hline
\end{tabular}

Adsorption conditions $400 \mathrm{mg} / \mathrm{L}$ thorium concentration, $40 \mathrm{~min}$ contact time, room temperature, $\mathrm{pH} 3.6,100 \mathrm{~mL}$ of thorium solution and $0.5 \mathrm{~g}$ modified $\mathrm{AC}$ dose

the adsorption rate constant $\left(\mathrm{min}^{-1}\right)$, which is determined by plotting $\log \left(\mathrm{q}_{\mathrm{e}}-\mathrm{q}_{\mathrm{t}}\right)$ versus $\mathrm{t}$ (Fig. 12).
From the data in (Table 5), the sorption capacity was found $60.64 \mathrm{mg} / \mathrm{g}$, and $\mathrm{R}^{2}$ value was 0.9864 . Accordingly, the adsorption processes for the modified AC does not fit a pseudo-first order kinetic model.

Results were also applied to the pseudo-second order kinetic model which is given in the following form [45]:

$t / q_{t}=1 / k_{2} q_{e}^{2}+\left(1 / q_{e}\right) t$

where $k_{2}$ is the rate constant ( $\left.\mathrm{g} / \mathrm{mg} \mathrm{min}\right)$. The slope of the straight lines of plots of $t / q_{t}$ versus $t$ stands for $1 / q_{e}$ while the intercept stands for $1 / k_{2} q^{2} e$ (Fig. 13). The calculated value $\left(\mathrm{q}_{\mathrm{e}}\right)$ for modified $A C$ was found to be $77.51 \mathrm{mg} / \mathrm{g}$ and the correlation coefficient $\left(R^{2}\right)=0.9968$, (Table 5). The obtained experimental data fit well with the pseudo-second order kinetic model. Accordingly, the pseudo second order model is the most suitable model to describe the
Fig. 13 Pseudo second order model of $\mathrm{Th}^{4+}$ adsorption by AC modified with TPPO

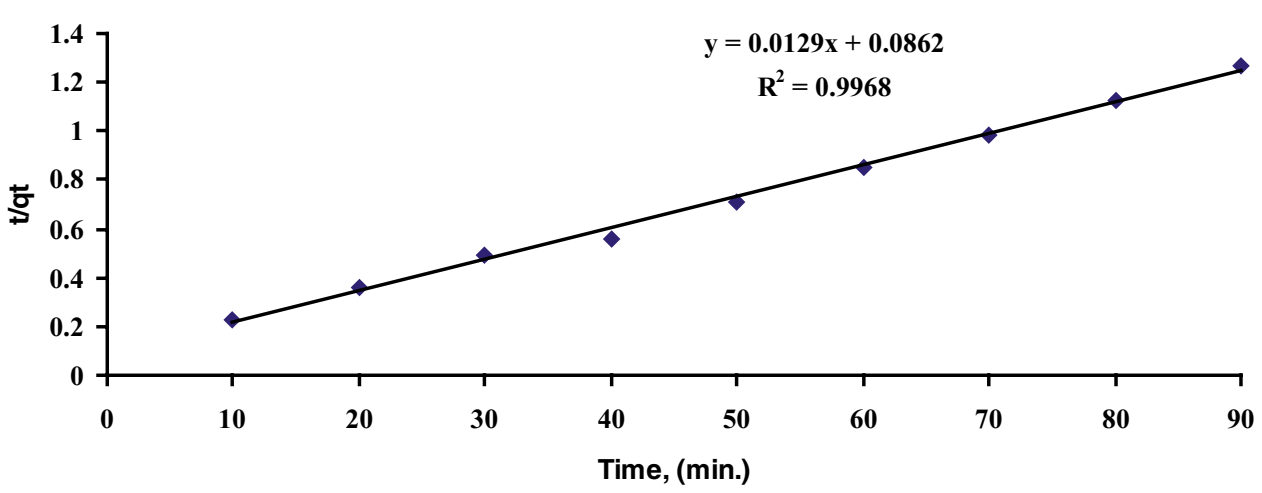


Fig. 14 SEM and EDX analyses of the thorium precipitate

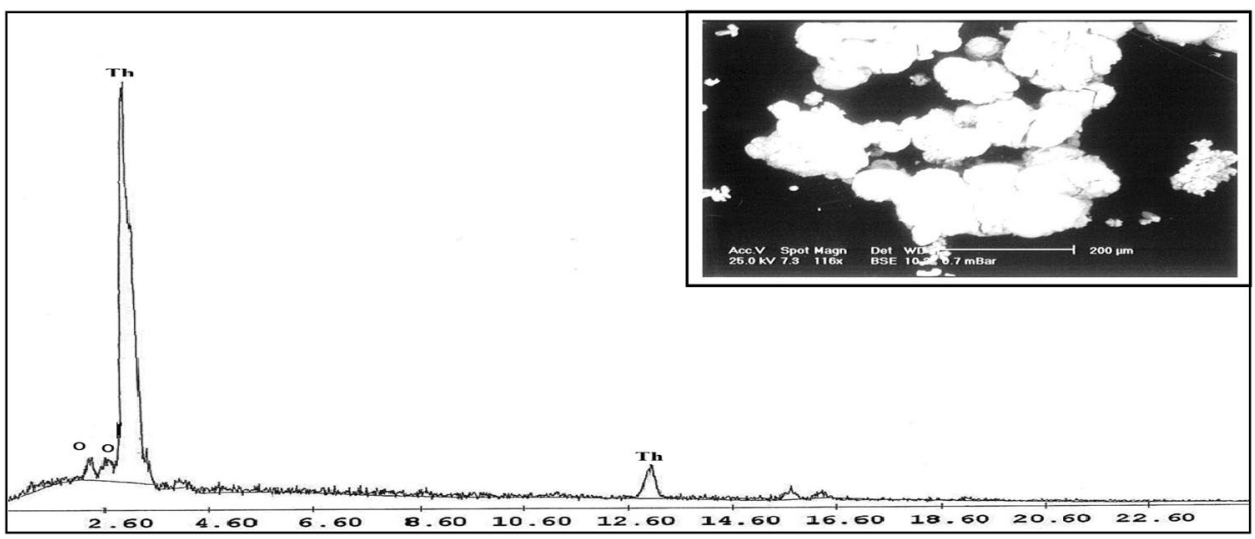

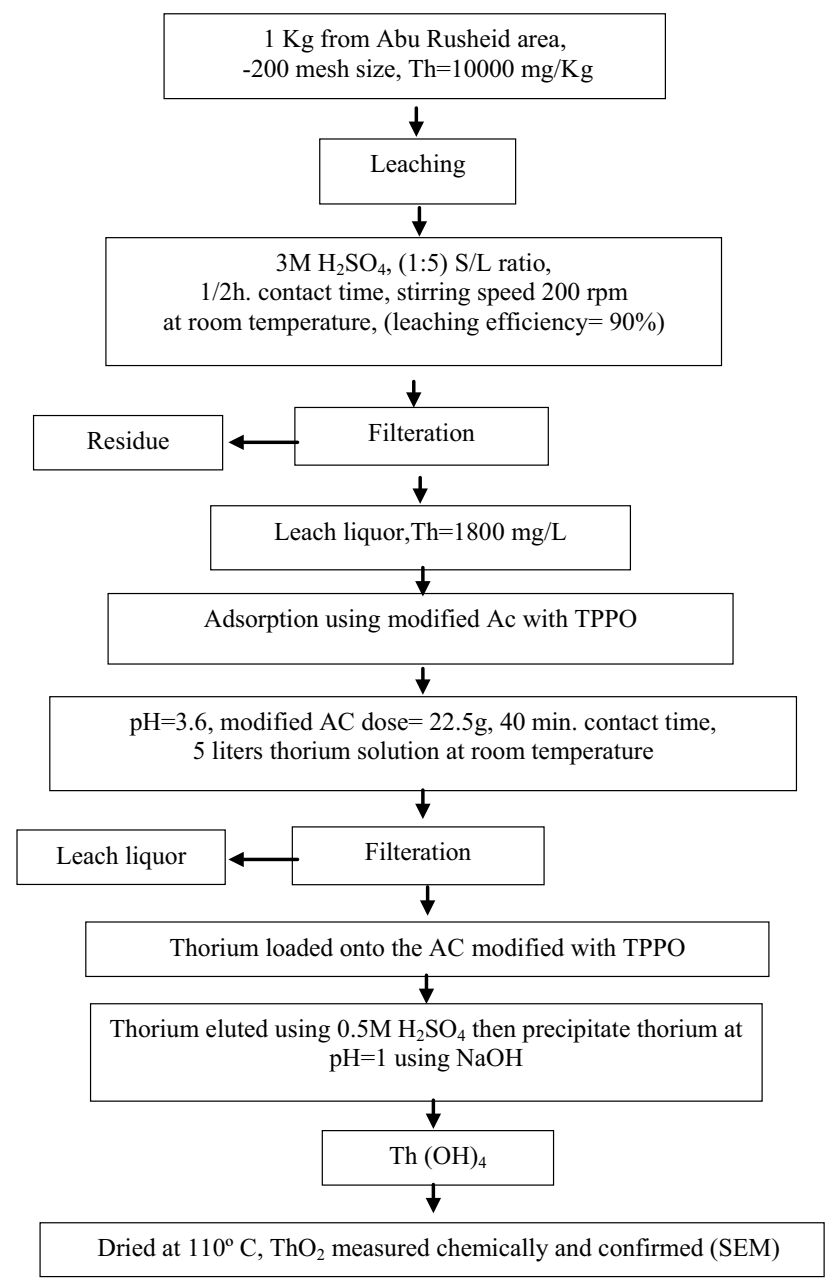

Fig. 15 Schematic flow diagram for the recovery of thorium from Abu-Rusheid area ore sample, SE desert, Egypt

kinetic process of thorium adsorption by the modified AC. This kinetic process is mainly controlled by the chemisorption which involves chemical bonding between thorium ions and the active sites of the modified AC $[46,47]$.
Table 6 Comparison of uptake capacities $(\mathrm{mg} / \mathrm{g})$ of different adsorbents towards $\mathrm{Th}^{4+}$

\begin{tabular}{|c|c|c|}
\hline Adsorbent & $\begin{array}{l}\text { Uptake capac- } \\
\text { ity }(\mathrm{mg} / \mathrm{g})\end{array}$ & References \\
\hline Lewatit S1468 & 499.91 & [48] \\
\hline $\begin{array}{l}\text { Carbamoylmethylphosphine } \\
\text { oxide_crosslinked polymer } \\
\text { (CMPO) }\end{array}$ & 25.98 & [49] \\
\hline Merrifield polymer-DMDBMA & 15.54 & {$[50]$} \\
\hline Magnetic chitosan composite & 312.5 & {$[51]$} \\
\hline Water hyacinth roots & 20 & {$[52]$} \\
\hline PEO/PLLA fibrous membranes & 50.1 & [53] \\
\hline Methacrylic acid/bentonite & 111.36 & {$[54]$} \\
\hline Impregnated XAD-7 resin & 136.88 & {$[55]$} \\
\hline AC modified with TPPO & 71.94 & Present study \\
\hline
\end{tabular}

\section{Case study}

Obtained sample of Abu Rusheid weighing $1 \mathrm{~kg}$ with thorium content $10,000 \mathrm{mg} / \mathrm{kg}$ was ground to particle size -200 mesh and was subjected to acid leaching with $3.0 \mathrm{M} \mathrm{H}_{2} \mathrm{SO}_{4}$ with $\mathrm{S} / \mathrm{L}$ ratio of $1: 5$ for 30 min at room temperature. The leach liquor was filtered and thorium was measured in solution was found $1800 \mathrm{mg} / \mathrm{L}$; leaching efficiency was $90 \%$. Five liters of leaching solution were stirred with $22.5 \mathrm{~g}$ of modified AC at pH 3.6 at $200 \mathrm{rpm}$ stirring speed for $40 \mathrm{~min}$. Thorium(IV) was eluted from the loaded modified AC using $0.5 \mathrm{M} \mathrm{H}_{2} \mathrm{SO}_{4}$ acid and was precipitated using sodium hydroxide at $\mathrm{pH} 1$ as thorium hydroxide then dried at $110^{\circ} \mathrm{C}$ as thorium oxide powder. The thorium assayed $83 \%$ in the product with $94.3 \%$ purity. The chemical composition of thorium precipitate was characterized by SEM and EDX analyses, (Fig. 14). Finally, a schematic flow diagram for the process is presented in (Fig. 15). A comparative study [48-55] of thorium uptake capacities $(\mathrm{mg} / \mathrm{g})$ of different adsorbents is shown in (Table 6). 


\section{Conclusion}

Activated carbon modified with TPPO was used for thorium(IV) adsorption at optimum conditions: $\mathrm{pH}$ 3.6, $200 \mathrm{rpm}$ agitation speed for $40 \mathrm{~min}$ at $25^{\circ} \mathrm{C}$. The maximum uptake capacity of the modified AC was $71.94 \mathrm{mg} / \mathrm{g}$. The obtained data obeyed pseudo-second order kinetic model. Langmuir adsorption isotherm model was found to be the most suitable model for explaining the adsorption process. Finally, the optimized factors have been carried out for thorium adsorption and precipitation from the studied leach liquor of a geologic sample. The final thorium precipitate was measured chemically and characterized by SEM and EDX analyses.

Acknowledgements This research paper was carried out as a part of the research activities of the authors. This article was reviewed and approved for publishing by the Nuclear Materials Authority. Despite that all the laboratories, instrumentations and chemicals were provided by the Nuclear Materials Authority; the authors still maintain the full right to publish the manuscript wherever they decide without any conflict of interest with the Nuclear Materials Authority.

\section{Compliance with ethical standards}

Conflict of interest The authors declare that they have no conflict of interest.

Disclosures and disclaimer This work was funded by the Nuclear Materials Authority as a part of its research activities. This article was reviewed and approved for publishing by the Nuclear Materials Authority with no obligation on the authors' part to revise the manuscript.

Ethical approval This article does not contain any studies with human participants or animals performed by any of the authors.

Informed consent None.

\section{References}

1. Cheira MF, Orabi AS, Atia BM, Hassanein MA (2018) Solvent extraction and separation of thorium(IV) from chloride media by a Schiff base. J Solut Chem 47(4):611-633. https://doi. org/10.1007/s10953-018-0740-1

2. Kaygun AK, Akyil S (2007) Study of the behaviour of thorium adsorption on PAN/zeolite composite adsorbent. J Hazard Mater 147:357-362. https://doi.org/10.1016/j.jhazmat.2007.01.020

3. Talip Z, Eral M, Hicsonmez U (2009) Adsorption of thorium from aqueous solutions by perlite. J Environ Radioact 100:139-143. https://doi.org/10.1016/j.jenvrad.2008.09.004

4. Sheng G, Hu B (2013) Role of solution chemistry on the trapping of radionuclide $\mathrm{Th}(\mathrm{IV})$ using titanate nanotubes as an efficient adsorbent. J Radioanal Nucl Chem 298(1):455-464. https://doi. org/10.1007/s10967-012-2389-3

5. Kaynar UH, Sabikoglu I, Kaynar SC, Eral M (2016) Modeling of thorium(IV) ions adsorption onto a novel adsorbent material silicon dioxide nano-balls using response surface methodology. Appl Radiat Isot 115:280-288. https://doi.org/10.1016/j.aprad iso.2016.06.033

6. Murty BS, Yeh JW, Ranganathan S, Bhattacharje PP (2019) Physical metallurgy of high-entropy alloys. High Entropy Alloys 3:3150. https://doi.org/10.1016/B978-0-12-816067-1.00003-5

7. Schibille N, Gratuze B, Ollivier E, Blondeau E (2019) Chronology of early Islamic glass compositions from Egypt. J Archaeol Sci 104:10-18. https://doi.org/10.1016/j.jas.2019.02.001

8. Heyerdahl H, Krogh C, Borrebæk J, Larsen A, Dahle J (2011) Treatment of HER2-expressing breast cancer and ovarian cancer cells with alpha particle-emitting ${ }^{227}$ Th-Trastuzumab. Int J Radiat Oncol Biol Phys 79(2):563-570. https://doi.org/10.1016/j.ijrob p.2010.08.038

9. Bhainsa KC, D'Souza SF (2009) Thorium biosorption by Aspergillus fumigatus, a fila-mentous fungal biomass. J Hazard Mater 165:670-676. https://doi.org/10.1016/j.jhazmat.2008.10.033

10. Deng Q, Jin Y, Wang Q, Zhao R, Pan N, Zhai F, Luo M, Xia C (2013) New cyclen derivative ligand for thorium(IV) separation by solvent extraction. J Radioanal Nucl Chem 295:125-133. https:// doi.org/10.1007/s10967-012-1879-7

11. Anirudhan TS, Suchithra PS, Senan P, Tharun AR (2012) Kinetic equilibrium profiles of adsorptive recovery of thorium(IV) from aqueous solutions using poly (methacrylic acid) grafted cellulose/bentonite superabsorbent composite. Ind Eng Chem Res 51:4825-4836. https://doi.org/10.1021/ie202538q

12. Deb AKS, Mohanty BN, Ilaiyaraja P, Sivasubramanian K, Venkatraman B (2012) Adsorptive removal of thorium from aqueous solution using diglycolamide functionalized multi-walled carbon nanotubes. J Radioanal Nucl Chem 295:1161-1169. https://doi. org/10.1007/s10967-012-1899-3

13. Pan N, Deng J, Guan D, Jin Y, Xia C (2013) Adsorption characteristics of Th(IV) ions on reduced graphene oxide from aqueous solutions. Appl Surf Sci 287:478-483. https://doi.org/10.1016/j. apsusc.2013.10.004

14. Cortina JL, Warshawsky A (1997) Developments in solid-liquid extraction by solvent-impregnated resins. Ion Exch Solvent Extr 13:195-293. https://pure.tue.nl/ws/files/3135867/200910950. pdf

15. Turanov AN, Karandashev VK, Masalov VM, Zhokhov AA, Emelchenko GA (2013) Adsorption of lanthanides(III), uranium(VI) and thorium(IV) from nitric acid solutions by carbon inverse opals modified with tetraphenyl methylene diphosphine dioxide. J Colloid Interface Sci 405:183-188. https://doi. org/10.1016/j.jcis.2013.05.026

16. Bansal RC, Donnet JB, Stoeckli F (1988) A review of: active carbon. J Dispers Sci Technol 11(3):323-482. https://doi. org/10.1080/01932699008943255

17. Qandeer R, Hanif J (1995) Adsorption of dysprosium ions on activated charcoal from aqueous solutions. Carbon 33(2):215-220. https://doi.org/10.1016/00086223(94)00135-M

18. Marczenko Z (1986) Separation and spectrophotometric determination of elements. Horwood, NewYork. ISBN-13: 978-0853129035

19. Shapiro L, Brannock WW (1962) Rapid analysis of silicates, carbonates and phosphate rocks. US Geol Surv Bull 114:51-53. https://doi.org/10.3133/b1144a

20. Zhou $\mathrm{H}$, Chen $Y$ (2010) Effect of acidic surface functional groups on $\mathrm{Cr}(\mathrm{VI})$ removal by activated carbon from aqueous solution. Rare Met 29:333-338. https://doi.org/10.1007/s1259 8-010-0059-6

21. Dong J, Ozaki Y (1997) FTIR and FT-Raman studies of partially miscible poly(methy 1 methacrylate)/poly(4-vinylphenol) blends in solid states. Macromolecules 30:286-292. https://doi. org/10.1021/ma9607168 
22. Ferrah N, Abderrahim O, Didi MA, Villemin D (2011) Sorption efficiency of a new sorbent towards uranyl: phosphonic acid grafted Merrifield resin. J Radioanal Nucl Chem 289(3):721730. https://doi.org/10.1007/s10967-011-1172-1

23. Langmuir D, Herman JS (1980) The mobility of thorium in natural waters at low temperatures. Geochim Cosmochim Acta 44:1753-1766. https://doi.org/10.1021/ja02242a004

24. Wang $H$, Yuan $X$, Wu $Y$, Huang $H$, Zeng $G$, Liu $Y$, Wang $X$, Lin NQY (2013) Adsorption characteristics and behaviors of graphene oxide for $\mathrm{Zn}$ (II) removal from aqueous solution. Appl Surf Sci 279:432-440. https://doi.org/10.1016/j.apsusc.2013.04.133

25. Torapava N, Persson I, Eriksson L, Lundberg D (2009) Hydration and hydrolysis of thorium(IV) in aqueous solution and the structures of two crystalline thorium(IV) hydrates. Inorg Chem 48:11712-11723. https://doi.org/10.1021/ic901763s

26. Mishra SP, Achary PG, Das M (2012) Adsorption of Cu(II) by used aqua guard carbon (UAC). J Chem Pharm Res 4(2):12071216. ISSN: 0975-7384

27. Sharma I, Goyal D (2009) Kinetic modeling: Chromium(III) removal from aqueous solution by microbial waste biomass. J Sci Ind Res 68:640-646. http://hdl.handle.net/12345 6789/4427

28. Miraoui A, Didi MA (2015) Thorium(IV) sorption onto sodium bentonite and magnetic bentonite. Eur Chem Bull 4(11):512521. https://doi.org/10.17628/ECB.2015.4.512

29. Liao XP, Shi B (2005) Adsorption of fluoride on zirconium(IV)impregnated collagen fiber. Environ Sci Technol 39:4628-4632. https://doi.org/10.1021/es0479944

30. Chaudhary N, Balomajumder C (2014) Optimization study of adsorption parameters for removal of phenol on aluminum impregnated fly ash using response surface methodology. J Taiwan Inst Chem Eng 45(3):852-859. https://doi.org/10.1016/j. jtice.2013.08.016

31. Kannamba B, Reddy KL, AppaRao BV (2010) Removal of Cu(II) from aqueous solutions using chemically modified chitosan. J Hazard Mater 175(1-3):939-948. https://doi.org/10.1016/j. jhazmat.2009.10.098

32. Chabani M, Amrane A, Bensmaili A (2006) Kinetic modelling of the adsorption of nitrates by ion exchange resin. Chem Eng J 125:111-117. https://doi.org/10.1016/j.cej.2006.08.014

33. Langmuir I (1918) The adsorption of gases on plane surfaces of glass, mica and platinum. J Am Chem Soc 40(9):1361-1403. https://doi.org/10.1021/ja02242a004

34. Sadeek SA, El-Sayed MA, Amine MM, Abd El-Magied MO (2014) Selective solid-phase extraction of $\mathrm{U}(\mathrm{VI})$ by amine functionalized glycidyl methacrylate. Environ Chem Eng 2:293-303. https ://doi.org/10.1016/j.jece.2013.12.015

35. Tag El-Din AF, Elshehy EA, Abd El-Magied MO, Atia AA, El-Khouly ME (2018) Decontamination of radioactive cesium ions using ordered mesoporous monetite. RSC Adv 8:19041-19050. https ://doi.org/10.3390/colloids1010002

36. Abd El-Magied MO, Dhmees AS, Abd El-Hamid AM, Eldesouky EM (2018) Uranium extraction by sulfonated mesoporous silica derived from blast furnace slag. J Nucl Mater 509:295-304. https ://doi.org/10.1016/j.jnucmat.2018.06.034

37. Abd El-Magied MO, Mansour A, Alsayed FA, Atrees MS, Abd Eldayem S (2018) Biosorption of beryllium from aqueous solutions onto modified chitosan resin: equilibrium, kinetic and thermodynamic study. Dispers Sci Technol 39:1597-1605. https ://doi.org/10.1080/01932691.2018.1452757

38. Elshehy EA, Shenashen MA, Abd El-Magied MO, El-Nahas AM, Tolan DA, Halada K, Atia AA, El-Safty SA (2017) Selective recovery of silver (I) ions from e-waste using cubically multi-thiolated cage mesoporous monoliths. Eur J Inorg Chem 2017:4823-4833. https://doi.org/10.1002/ejic.201700644
39. Abd El-Magied MO, Tolba AA, El-Gendy HS, Zaki SA, Ati AA (2017) Studies on the recovery of Th(IV) ions from nitric acid solutions using amino-magnetic glycidyl methacrylate resins and application to granite leach liquors. Hydrometallurgy 169:89-98. https ://doi.org/10.1016/j.hydromet.2016.12.011

40. Abd El-Magied MO, Hassan AM, Gad HMH, Mohammaden TF, Youssef MAM (2017) Removal of nickel(II) ions from aqueous solutions using modified activated carbon: a kinetic and equilibrium study. J Dispers Sci Technol 39:862-873. https://doi. org/10.1080/01932691.2017.1402337

41. Tunali S, Akar T (2006) Zn (II) biosorption properties of Botrytis cinerea biomass. J Hazard Mater 131(1-3):137-145. https://doi. org/10.1016/j.jhazmat.2005.09.024

42. Humelnicu D, Drochioiu G, Sturza MI, Cecal A, Popa K (2006) Kinetic and thermodynamic aspects of $\mathrm{U}(\mathrm{VI})$ and Th(IV) sorption on a zeolitic volcanic tuff. J Radioanal Nucl Chem 270(3):637640. https://doi.org/10.1007/s10967-006-0473-2

43. Freundlich HMF (1906) Over the adsorption in solution. Phys Chem 57:385-470

44. Lagergren S (1898) About the theory of so called adsorption of soluble substance. Kungliga Svenska Vetenskapsakademiens, Handlinger 24:1-39

45. Zhang X, Jiao C, Wang J, Liu Q, Li R, Yang P (2012) Removal of uranium $(\mathrm{VI})$ from aqueous solutions by magnetic schiff base: kinetic and thermodynamic investigation. Chem Eng J 198:412419. https://doi.org/10.1016/j.cej.2012.05.090

46. Wu FC, Tseng RL, Juang RS (2001) Enhanced abilities of highly swollen chitosan beads for color removal and tyrosinase immobilization. J Hazard Mater 81:167-177. https://doi.org/10.1016/ S0304-3894(00)00340-X

47. Ding L, Deng HP, Wu C, Han X (2012) Affecting factors, equilibrium, kinetics and thermodynamics of bromide removal from aqueous solutions by MIEX resin. Chem Eng J 181:360-370. https://doi.org/10.1016/j.cej.2011.11.096

48. Mahmoud AAA, Fatih C, Sabriye Y, Ceren KA (2017) Assessment of the adsorption of thorium onto styrene divinylbenzenebased resin: optimization using central composite design and thermodynamic parameters. Process Saf Environ Prot 109:192202. https://doi.org/10.1016/j.psep.2017.02.019

49. Annam S, Brahmmananda CVS, Sivaraman N, Sivaramakrishna A, Vijayakrishna K (2018) Carbamoylmethylphosphine oxide functionalised porous crosslinked polymers towards sequential separation of uranium(VI) and thorium(IV). React Funct Polym 131:203-210. https://doi.org/10.1016/j.reactfunctpolym .2018.07.026

50. Ansari SA, Mohapatra PK, Manchanda VK (2009) A novel malonamide grafted polystyrene-divinyl benzene resin for extraction, pre-concentration and separation of actinides. J Hazard Mater 161(2-3):1323-1329. https://doi.org/10.1016/j.jhazm at.2008.04.093

51. Hritcu D, Humelnicu D, Dodi G, Popa MI (2012) Magnetic chitosan composite particles: evaluation of thorium and uranyl ion adsorption from aqueous solutions. Carbohydr Polym 87:11851191. https://doi.org/10.1016/j.carbpol.2011.08.095

52. Ashraf A, Hany AA, Shawky S, Kandil AT (2014) Separation of thorium from aqueous solution by non living water hyacinth roots. Tech J Eng Appl Sci 4(1):1-10. ISSN 2051-0853 @2014 TJEAS

53. Savva I, Efstathiou M, Krasia-Christoforou T, Pashalidis I (2013) Adsorptive removal of $\mathrm{U}(\mathrm{VI})$ and $\mathrm{Th}(\mathrm{IV})$ from aqueous solutions using polymer-based electrospun PEO/PLLA fibrous membranes. J Radioanal Nucl Chem 298(3):1991-1997. https://doi. org/10.1007/s10967-013-2657-x

54. Anirudhan TS, Rijith S, Tharun AR (2010) Adsorptive removal of thorium(IV) from aqueous solutions using poly(methacrylic acid)-grafted chitosan/bentonite composite matrix: process 
design and equilibrium studies. Colloids Surf A 368:13-22. https ://doi.org/10.1016/j.colsurfa.2010.07.0055

55. Hosseini-Bandegharaei A, Allahabadi A, Rahmani-Sani A, Rastegar A, Khamirchi R, Mehrpouyan M, Hekmat-Shoar R, Pajohankia Z (2016) Thorium removal from weakly acidic solutions using titan yellow-impregnated XAD-7 resin beads kinetics, equilibrium and thermodynamic studies. J Radioanal Nucl Chem 309(2):761-776. https://doi.org/10.1007/s10967-015-4689-x

Publisher's Note Springer Nature remains neutral with regard to jurisdictional claims in published maps and institutional affiliations. 